\title{
Relationship of Epiphytic Growth of Mycosphaerella citri to Greasy Spot Development on Citrus and to Disease Control with Fenbuconazole
}

\author{
S. N. Mondal, Assistant in Plant Pathology, and L. W. Timmer, Professor, University of Florida, Citrus Research \\ and Education Center, Lake Alfred 33850
}

\begin{abstract}
Mondal, S. N., and Timmer, L. W. 2003. Relationship of epiphytic growth of Mycosphaerella citri to greasy spot development on citrus and to disease control with fenbuconazole. Plant Dis. 87:186-192.

Greasy spot, caused by Mycosphaerella citri, produces foliar lesions and severe defoliation of citrus trees. Ascospore production and deposition by M. citri, development of epiphytic growth, and symptoms were monitored on grapefruit trees in the field and on rough lemon trap plants for 2 years. Ascospore production and deposition peaked in April to May both years. However, epiphytic mycelium did not develop extensively until the summer rainy season was well underway in July. Some epiphytic growth and symptoms formed on trap plants placed in the grove for 2-week periods throughout the year. In the summer, epiphytic growth was apparent 15 days after the exposure period, and symptoms appeared about 60 days after exposure, but development was much slower in cooler and drier months. One or two fenbuconazole applications before the development of epiphytic mycelium in July completely controlled greasy spot on spring growth leaves for 12 to 18 months. Applications in July or August were less effective. Epiphytic mycelium developed more rapidly on summer growth; therefore, fungicide applications need to be timed more precisely.
\end{abstract}

Greasy spot, caused by Mycosphaerella citri Whiteside, is one of the most important foliar fungal diseases of citrus in the Caribbean Basin, including Florida, the Caribbean islands, eastern Mexico, and Central America $(1,5)$. The disease produces yellow-brown spots on the underside of mature leaves and induces premature defoliation that reduces yield and fruit size $(6,12)$. M. citri also infects fruit and produces greasy spot rind blotch that affects the external quality and marketability of the fruit (5). Greasy spot affects all citrus but is most severe on lemon and grapefruit.

The basic biology and disease cycle of M. citri have been well studied $(6,8,9,11)$. The pathogen produces ascospores in pseudothecia in the decomposing leaf litter. Ascospores are airborne and disseminated by wind to the leaf surface. There, they germinate and mycelium grows epiphytically for weeks prior to penetration through the stomates $(5,9)$. Development

Corresponding author: S. N. Mondal

E-mail: smondal@lal.ufl.edu

This research was supported by the Florida Agricultural Experiment Station, and approved for publication as Journal Series No. R-08957

This research was supported in part by the Florida Citrus Production Research Advisory Council, Projects 991-36P and 013-16P.

Accepted for publication 2 October 2002.

Publication no. D-2003-1213-01R

(C) 2003 The American Phytopathological Society and penetration occurs only on the abaxial side of the leaf because citrus has few stomates on the adaxial surface. The fungus develops slowly in the mesophyll of the leaf, and symptoms may not develop for 3 to 4 months after infection. Symptoms develop more rapidly on highly susceptible lemon and grapefruit than on orange and more slowly on tolerant mandarin. Greasy spot-induced leaf drop occurs in February to March in Florida $(6,8,9)$. Pseudothecia and ascospores are produced in leaf litter as it decomposes.

Although the basic biology and the disease cycle are understood, the timing of the different stages varies with environmental and cultural conditions. Whiteside found that peak ascospore release coincided with the beginning of the summer rainy season in June (9). Epiphytic growth and penetration then occurred during warm, humid conditions in the summer. Thus, fungicide sprays could be timed according to the release of ascospores. However, the change to microsprinkler irrigation, where leaf litter was wetted much more frequently, advanced the maturation of pseudothecia and ascospores $(2,6)$. Peaks now occur more commonly in April and May (7), and the best timing of applications is uncertain.

Some infection by $M$. citri occurs year round (8). Despite the peak of ascospores in April to May, most of the infection still occurs from June to September. Summer months are favorable for epiphytic development (11); therefore, infections may result even though few ascospores are produced at that time. Alternatively, co- nidia, produced on epiphytic mycelium, may be responsible for some infection (9). In the original studies, conidia were thought to be of only minor importance in the disease development $(9,11)$.

Fungicide applications have been made on a calendar basis (7), and the best timing of single applications varies from May to July $(8,10,13)$. Some attempts have been made to time applications according to peaks in ascospore production (3). Epiphytic growth precedes infection; therefore, its presence may be more useful in timing fungicide sprays. The relationship of epiphytic growth to symptom development at different times of the year has not been investigated. These studies were undertaken to determine that relationship and the effect of fungicide sprays at different times of the year on epiphytic growth and subsequent symptom development.

\section{MATERIALS AND METHODS}

Experimental site and plant material. Field studies were conducted in a mature grove of grapefruit (Citrus paradisi Macf.) located at the Citrus Research and Education Center in Lake Alfred, FL. No fungicides were applied to the trees, but occasional acaricide applications were made for mite control. An automated weather station located within $500 \mathrm{~m}$ of the grove provided rainfall and temperature data.

Rough lemon (C. jambhiri Lush) trap plants were used to follow ascospore deposition, epiphytic growth, and symptom development. Seedlings were grown in the greenhouse as a single stem in 2.5-liter plastic pots in a soilless potting mix to a height of at least $1 \mathrm{~m}$. Prior to placement in the field, seedlings were pruned to a height of about $0.8 \mathrm{~m}$, leaving 30 to 40 mature leaves per plant. In the field, seedlings were placed next to affected trees and positioned so that the foliage was not wetted by the microsprinklers but was exposed to dew and rain. After exposure in the field, potted seedlings were removed and placed in the greenhouse where foliage was kept dry and monitored as needed for each experiment.

Ascospore trapping. A 7-day recording volumetric spore sampler (Burkard Scientific Sales, Ltd., Rickmansworth, Herfordshire, UK) was operated continuously at the field site during the 2000-01 and 2001-02 seasons. The spore trap tapes were coated first with a base layer of a mixture of gelvitol (35 g), glycerol (50 
$\mathrm{ml})$, phenol (2 $\mathrm{g})$, and distilled water (100 $\mathrm{ml})$. This was followed by a second layer consisting of a mixture of petroleum gel $(25 \mathrm{~g})$, paraffin wax (12 g), and toluene (about $50 \mathrm{ml}$; the amount was reduced in summer when temperatures were higher). Tapes were mounted and stained as previously described (8). The counts presented are the total number of ascospores counted on all tapes for each 2-week period.

Ascospore counts and epiphytic growth on leaves. The area of the leaves to be sampled was determined using a LiCor 3000 leaf area meter (Li-Cor, Inc., Lincoln, NE). Discs (7 $\mathrm{mm}$ in diameter) were cut from the leaves using a cork borer. Discs were cleared in $95 \%$ ethanol and lactophenol $(2: 1 \mathrm{vol} / \mathrm{vol})$ for 6 days following the method of Skaria and Zhang (4). Cleared discs were stained with $0.1 \%$ trypan blue in $50 \%$ glycerol for $24 \mathrm{~h}$, then rinsed two to three times with water and stored in 50\% glycerol until observed. All ascospores on the leaf discs were counted at $\times 200$ and were converted to the number of ascospores per leaf.

Discs were prepared similarly for examination of epiphytic growth. The abaxial surfaces of discs were examined at $\times 20$ and the density of epiphytic growth rated on a scale where $0=$ no visible epiphytic growth; $1=$ scattered hyphae, $<10 \%$ coverage; $2=10$ to $25 \%$ coverage; $3=26$ to $75 \%$ coverage; $4=76$ to $100 \%$ coverage; and $5=$ dense growth covering the entire disc surface.

Experimental procedures. Experiments were established to assess the relationship of airborne ascospores and ascospore deposition on foliage. Airborne ascospore numbers at the site were evaluated as described above. Six rough lemon trap plants were placed in the grove for each 2 -week period throughout the 2 years of the study. At the end of the 2-week exposure, two leaves were collected from each rough lemon trap plant. Ten 7-mm-diameter discs were cut from the two leaves and processed as described above and the number of ascospores counted. Area of the leaf was determined by the leaf area meter and the number of ascospores converted to the mean number of ascospores deposited per leaf \pm the standard error.

Cumulative deposition was determined on grapefruit leaves in the grove. Ten branches with new shoots at the beginning of the experiment were marked on each of six trees. One leaf was collected from each marked branch every 2 weeks, the leaf area was measured, one disc was cut from each leaf, and the discs were processed as described above. The number of ascospores was counted and expressed as the mean \pm the standard error per leaf.

The relationship between epiphytic mycelial growth and symptom development was evaluated using rough lemon trap plants. Six rough lemon trap plants were placed in the grove every 2 weeks. After
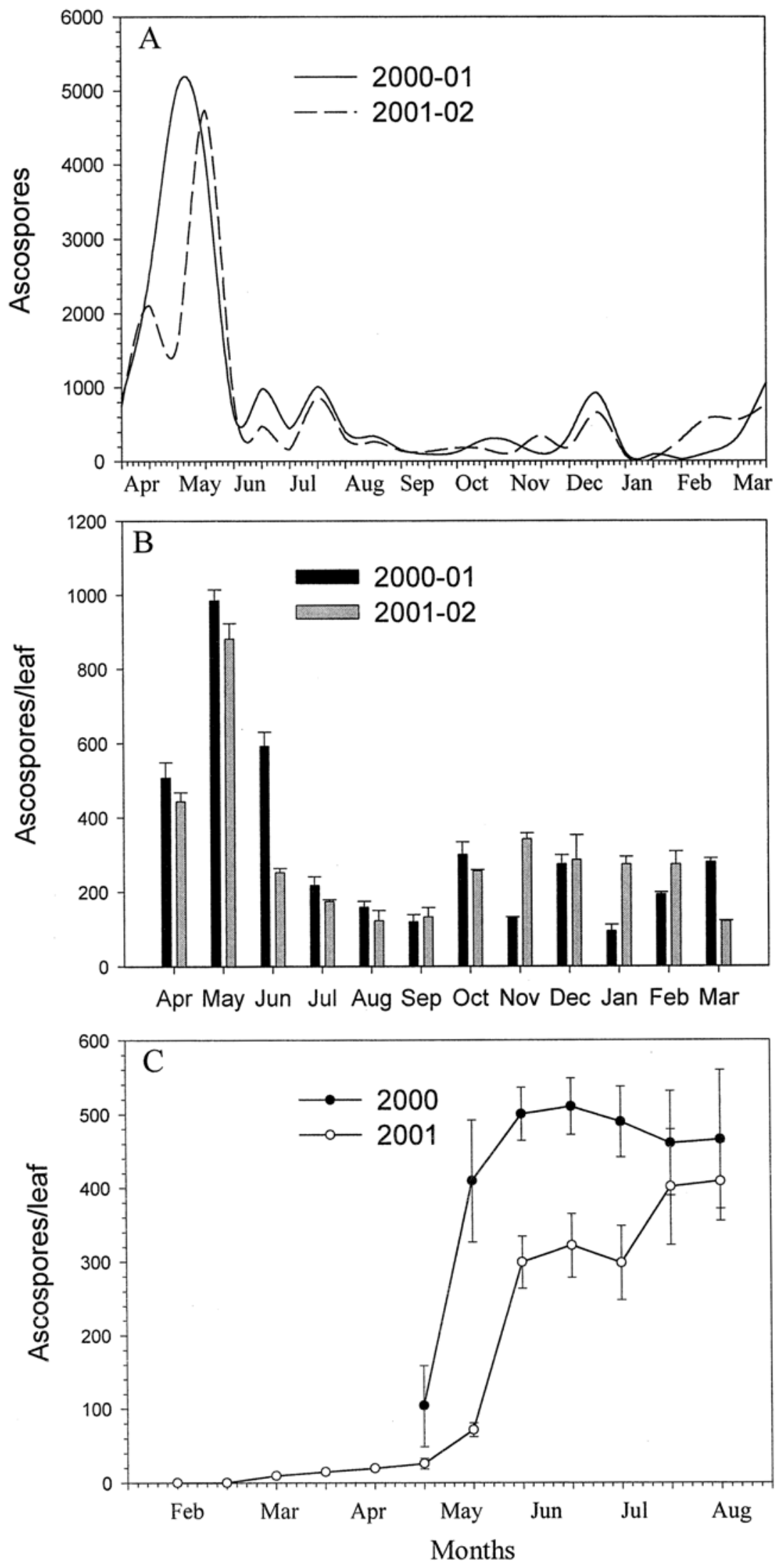

Fig. 1. Ascospore numbers captured in a spore trap and deposited on rough lemon trap plants and grapefruit leaves in the grove in 2000-01 and in 2001-02. A, Total ascospores captured every 2 weeks in a volumetric spore trap; $\mathbf{B}$, number of ascospores per leaf deposited on rough lemon trap plants placed in a grapefruit grove for 2-week periods; $\mathbf{C}$, cumulative ascospores deposited per leaf on grapefruit foliage in the grove. 
exposure, the plants were placed in the greenhouse and three were sampled destructively for evaluation of epiphytic growth, and three were monitored for symptom development. For assessment of epiphytic growth, two to three leaves were collected from each seedling and 10 discs (7 $\mathrm{mm}$ in diameter) were cut, processed, and rated for epiphytic growth as described other three trap plants were rated on a scale where $0=$ no symptoms, $1=1$ to $5 \%$ of the 11 to $15 \%, 4=16$ to $20 \%$, and $5=20 \%$ or leaf abscised. Only the actual lesion areas were considered in the ratings, and surrounding chlorotic areas were disregarded. Data presented for each month was the average of the two 2-week periods.

The effect of fungicide application at different times during the season on the epiphytic development of $M$. citri, disease incidence and severity, and defoliation was evaluated. Fenbuconazole, as Enable 2F, was sprayed to run-off at $0.5 \mathrm{ml} /$ liter of formulated product with a hand-pump sprayer at various times during the season to 20 branches each on six replicate trees, except for the July 2000 treatment, where three replicate trees were used. Fenbuconazole treatments in 2000-01 were (i) July, (iv) 14 August, and (v) 18 May + 14 June. In 2001-02, fenbuconazole treatments were (i) water-sprayed control, (ii) 12 June, (iii) 12 July, (iv) 14 August, and (v) 12 June +21 July. Of the 20 treated branches, 10 were destructively sampled for evaluation of epiphytic growth, and 10 were evaluated for greasy spot incidence, severity, and defoliation. To assess epiphytic growth, one leaf was collected from each branch (i.e., 10 per replicate) and one 7-mmdiameter disc cut from each. Discs were above. The top 15 leaves on each of the surface area with lesions, $2=6$ to $10 \%, 3=$ water-sprayed control, (ii) $18 \mathrm{May}$, (iii) 12

processed and rated for the amount of epiphytic growth as described above. Samples were collected and assessed every 2 weeks.

Symptoms were evaluated about every 3 months on the other 10 branches. The number of leaves with greasy spot as a percentage of the total was determined. Severity was rated on each shoot as described above. The percentage defoliation also was assessed on each date.

For the summer growth flush emerging in July, epiphytic growth and disease severity were evaluated by the same system. Only two treatments were evaluated: (i) a water-sprayed control and (ii) fenbuconazole applied on 17 July 2000 and on 22 July 2001.

\section{RESULTS}

Relationship of epiphytic growth and symptom development. The number of airborne ascospores peaked in early May 2000 and late May 2001 (Fig. 1A). Some ascospores were recovered during every sampling period, confirming year-round production of ascospores. However, numbers were low from August until March or April. The number of ascospores deposited on the surface of trap plant leaves followed a similar pattern (Fig. 1B). Comparatively high numbers of ascospores were observed on the leaf surface at times of the year when airborne ascospore numbers were low. Very few ascospores were detected on the grapefruit leaves of grove trees until peak releases began in late April and early May (Fig. 1C). Numbers on leaves of field trees increased rapidly until June and then leveled off. Ascospores became difficult to count after epiphytic mycelium became abundant in summer, and no further attempts were made to count spores. Ascospore release peaked before the summer rainy season began (Figs. 1A and 2).

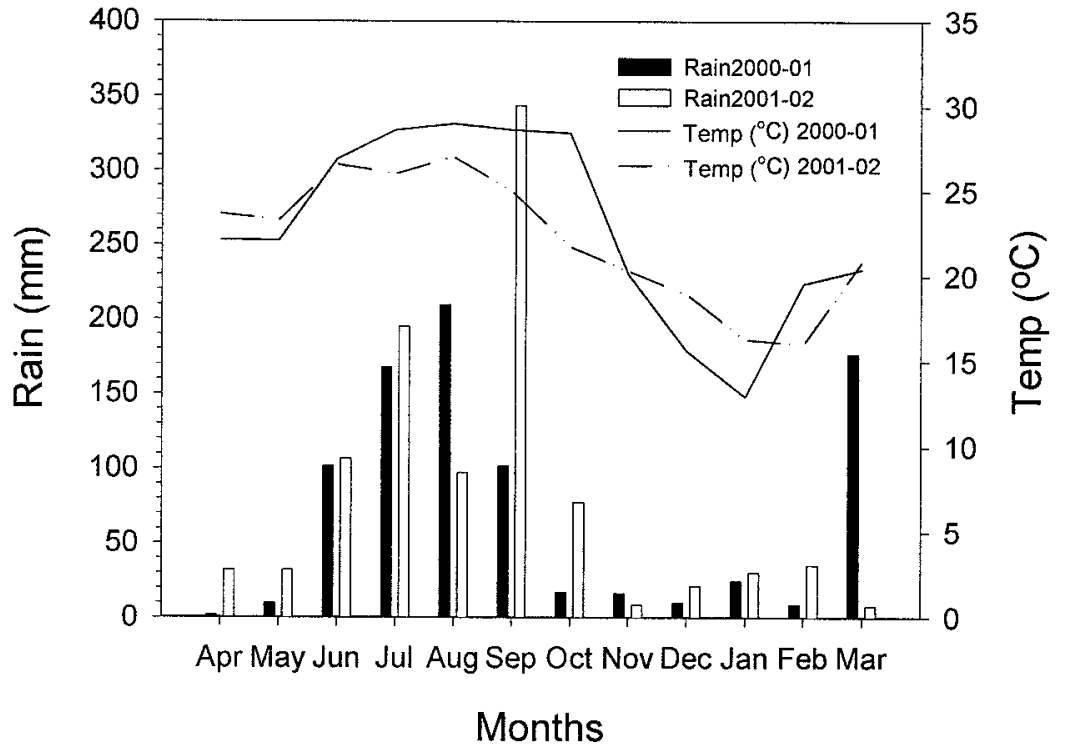

Fig. 2. Monthly rainfall totals and average temperatures in 2000-01 and 2001-02 seasons in Lake Alfred, FL.
Epiphytic mycelial growth and symptom development were monitored on trap plants exposed for 2-week periods for 2 years (Figs. 3 and 4). Very little epiphytic mycelial development occurred on plants exposed in December, January, and February during the 120 days following exposure. Almost no symptoms developed on plants exposed during those months in 2000, but some lesions were produced in 2001. Generally, epiphytic development was low to moderate in spring (March to April) and fall (October to November) in both years (Figs. 3 and 4). Symptom severity was higher in October to November 2001 (Fig. 4) than in the same period in 2000 (Fig. 3), even though temperature and rainfall did not differ greatly between the 2 years. During the summer months (May to September), epiphytic development was rapid and severe symptoms developed on rough lemon in 60 to 90 days (Figs. 3 and 4).

During the summer months, epiphytic mycelium was apparent 15 to 30 days after the exposure period. Some disease was apparent 45 to 60 days after the exposure period. Occasionally, symptoms were severe by 60 days after the exposure period. In the summer months, the first symptoms were apparent 15 to 30 days after epiphytic mycelium was detectable.

Effect of fenbuconazole applications on epiphytic growth and symptom development. Epiphytic growth in 2000 on unsprayed shoots was apparent in May, but remained at low levels until July (Fig. 5A), when the summer rains were well underway (Fig. 2). Maximum epiphytic growth was reached in August, and fungal growth did not increase or decline thereafter. May or July applications of fenbuconazole, and especially May + June applications, kept epiphytic growth at low levels through January. An August spray reduced already existing epiphytic growth below that of the unsprayed control, but growth was much greater than on shoots sprayed earlier.

A similar pattern was observed in 2002. Epiphytic growth was well developed in the control by late July on spring growth leaves (Fig. 5B). A single spray applied in June or two sprays in June + July kept epiphytic growth at low levels through the end of the year. A single July spray was slightly less effective, and a single August spray only moderately reduced the levels of epiphytic growth.

On summer shoots, epiphytic growth developed quickly on leaves formed in late June and early July in both years (Fig. 6A and B). A single application of fenbuconazole in late July maintained epiphytic growth at low levels for the remainder of the year.

Nine months after the emergence of the spring growth flush in 2000, greasy spot incidence and severity were low, and none of the leaves had fallen in any treatment (Table 1). After that, the disease progressed rapidly in the controls and somewhat more 
slowly in the shoots sprayed in August. Shoots receiving sprays in May, July, or May + June, were still relatively free of disease at 12 (March 2001) and 15 (June 2001) months after treatment. Even 18 months after the emergence of the shoots (September 2001), about 15 to 16 months after the May and May + June fungicide applications, disease incidence, severity, and defoliation were still very low and significantly less than the other treatments.

In 2001-02, disease incidence, severity, and the percent defoliation were monitored periodically in all fungicide treatments beginning at 7 months (October 2001) after shoot emergence or about 4 months after the June spray (Table 2). Disease incidence and severity were low to moderate in all treatments at 7 and 9 months, but there was no defoliation at that time. A single June spray or the June + July treatment was highly effective in reducing disease incidence, severity, and defoliation. A single spray in July was less effective than the above treatments, but more effective than a single spray in August. A single spray in August slowed disease progress, but was not highly effective for greasy spot control.

The disease progressed more rapidly on leaves of the summer growth flush in 2000 (Table 3). Symptoms were apparent 6 months after emergence of the shoots (December 2000) and moderate after 12 months (June 2001). A single spray of fenbuconazole significantly reduced greasy spot incidence and severity for the 12 months during which measurements were made.

A similar pattern was observed in 2001 (Table 4). Greasy spot incidence and severity in the unsprayed control were moderate in 2001 after 6 and 8 months and high after 10 months (April 2002). Some defoliation was evident in the control after 8 to 10 months. A single application of fenbuconazole reduced the disease to virtually nil for the next few months.

\section{DISCUSSION}

Many years ago, peak ascospore release of $M$. citri occurred in June to July, which coincided with summer rainy season (9). Conditions at that time of year were favorable for ascospore germination, development of epiphytic growth, and infection. In more recent years, ascospore peaks have occurred in April to May (8). Similar results were observed in this study. As pointed out previously $(5,8)$, these earlier peaks are probably due to the more frequent wetting of leaf litter by microsprinkler irrigation. Previously, leaf litter during the dry spring months was wetted only occasionally by overhead irrigation or infrequent rains delaying decomposition until the rainy season.

Ascospores are deposited on the leaves of trap plants and field trees in May coincident with the peak in airborne ascospores. Many ungerminated ascospores were observed on the leaf surface. Presumably these were recently deposited ascospores. Whiteside (11) felt ungerminated and recently germinated spores were rather short-lived, but it is possible that ungerminated spores could survive for some time and later germinate to produce epiphytic mycelium.
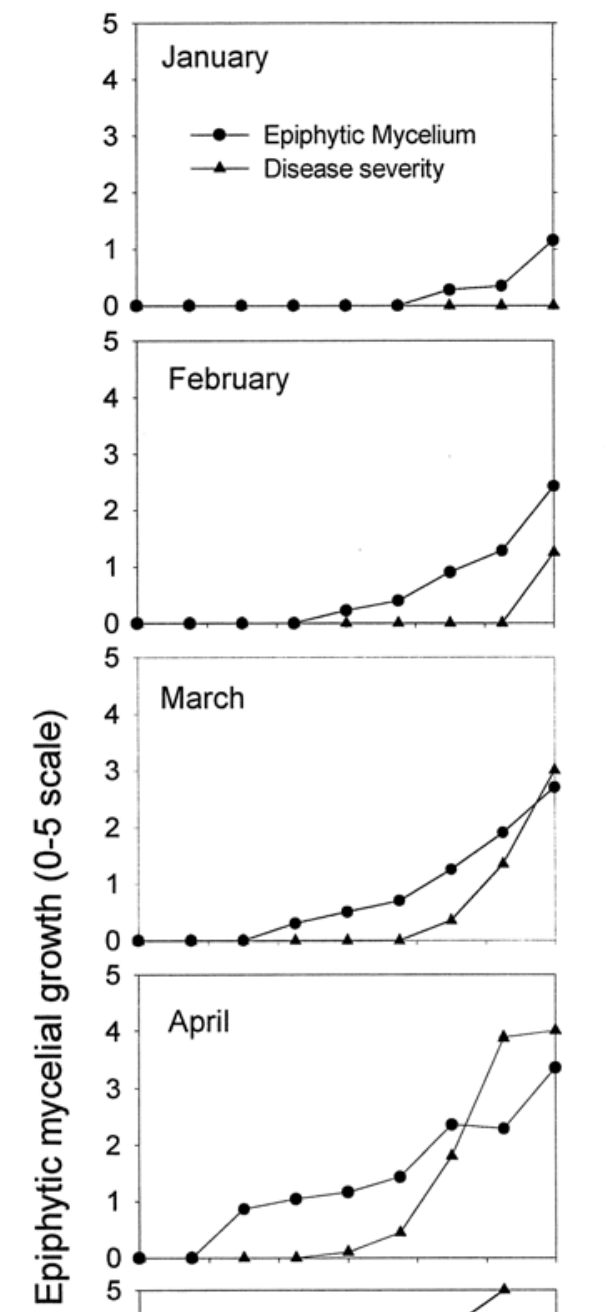

흠
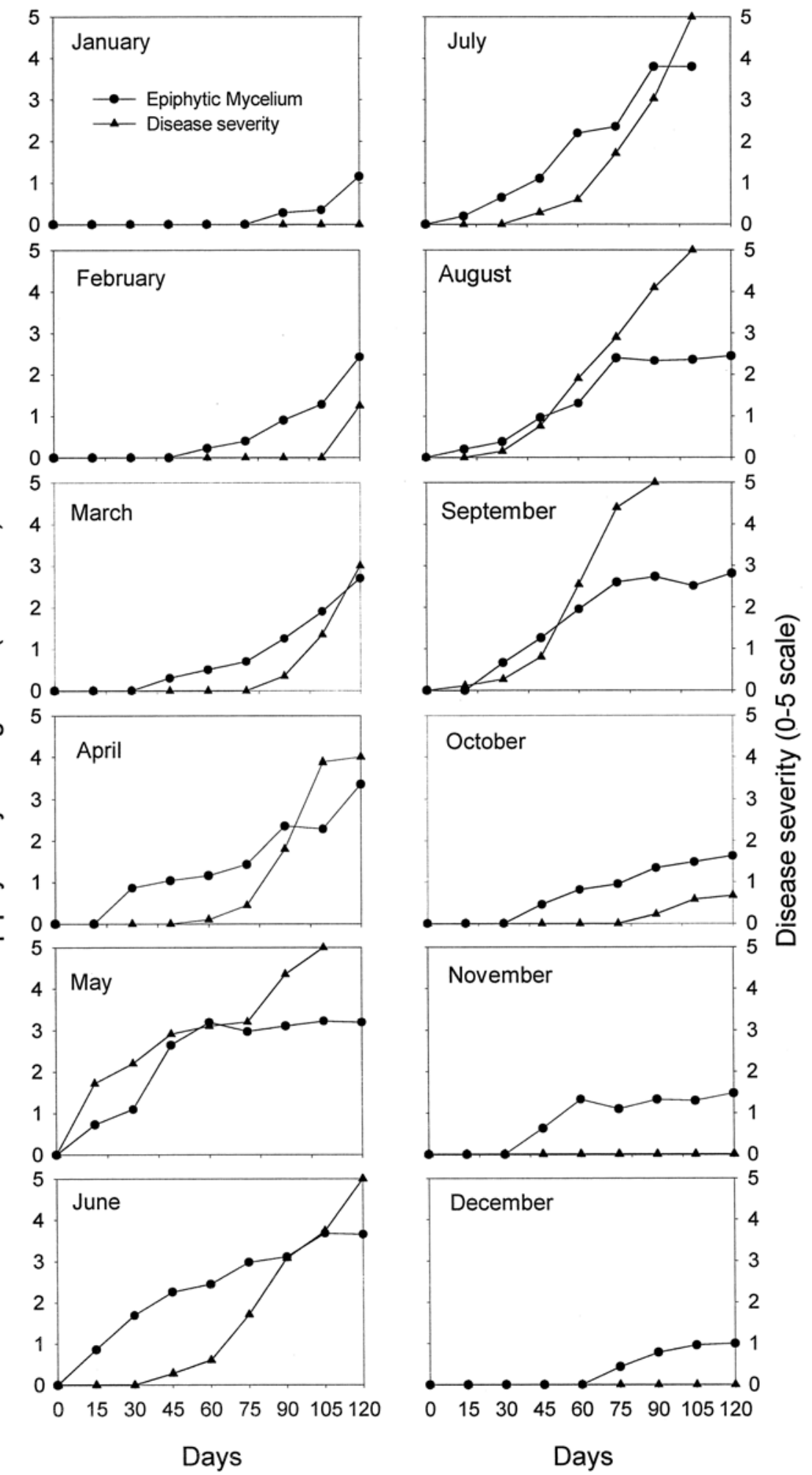

Days

Fig. 3. Epiphytic growth of Mycosphaerella citri and greasy spot disease severity followed for up to 120 days after rough lemon trap plants were exposed in the grove for a 2 -week period from April 2000 to March 2001. Each month is the average of two 2-week periods. 
and may be severe. The epiphytic growth may develop from ungerminated spores deposited in April to May or, alternatively, from the relatively low numbers released in June to July, when conditions for epiphytic growth are more favorable. Ascospores and mycelium from recently germinated ascospores survive for brief periods

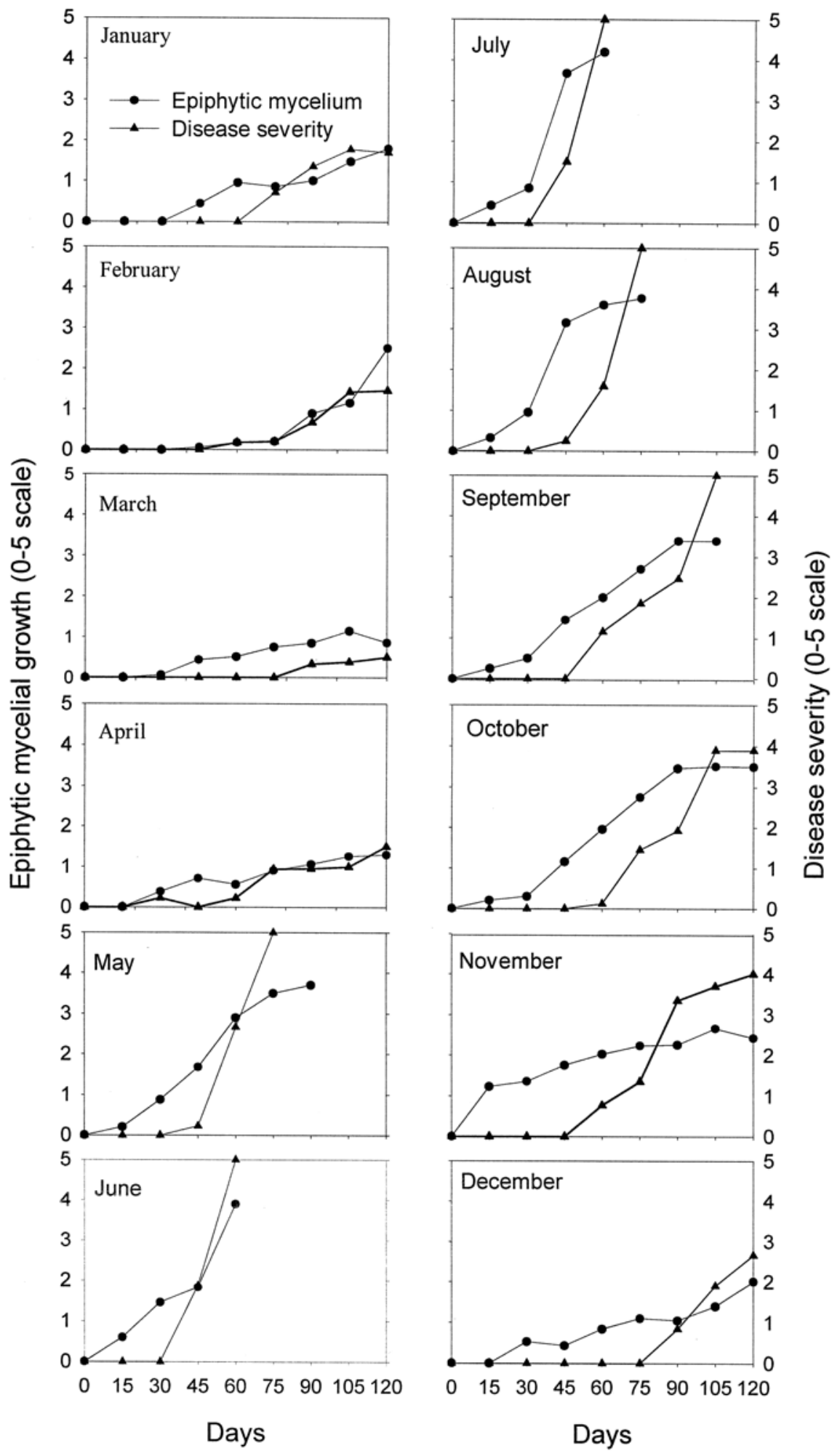

Fig. 4. Epiphytic growth of Mycosphaerella citri and greasy spot disease followed for up to 120 days after rough lemon trap plants were exposed in the grove for 2-week periods from April 2001 to March 2002. Each month is the average of two 2-week periods. result of infection by conidia. Conidia are not thought to be important in the disease cycle $(9,11)$. However, relatively large numbers are formed on the epiphytic growth $(9,11$; unpublished observations). Thus, conidia produced on the epiphytic growth on spring shoots could play a role in infection of summer shoots.

Epiphytic growth and symptoms may develop at any time during the year. Although conditions are most favorable in summer, short periods of warm, moist conditions can occur even in midwinter. Apparently, epiphytic growth developing during those months eventually produces symptoms. Thus, greasy spot occurs in overlapping cycles all year round. Less epiphytic growth develops in the drier months from October to May. Cool temperatures from November to February further slow epiphytic growth and symptom development. In contrast, epiphytic growth and symptom development is very rapid from June to September.

The long delay in the development of epiphytic mycelium in the spring allows a great deal of flexibility in timing of fungicide applications. Single fungicide applications made from April through July significantly reduced greasy spot severity (8). May and June sprays were usually the most effective. Timing of fungicide sprays based on ascospore peaks (3) probably is not necessary or effective. The essential aspect of timing is to apply sprays before significant epiphytic growth has developed. As long as sprays to the spring flush of growth are made prior to or early in the rainy season, disease control is very good.

Sprays to control greasy spot on the summer flush of growth may have to be made more promptly because epiphytic growth develops rapidly in summer. One of the problems with protecting summer flush is that shoots emerge sporadically all summer long. Growers may not be able to control the disease on all summer growth. They may have to wait until significant numbers of shoots have emerged and then spray within about a month of shoot expansion.

The longevity of control with a single fungicide spray is phenomenal. Even 15 to 18 months after a spray, very few symptoms have developed. This is due to several factors. First, the sprays are applied to fully expanded leaves, so there is no loss of coverage due to leaf expansion. All of the infection with $M$. citri occurs through the underside of the leaves because the stomates are located there. Fungicide residues on the abaxial surfaces are well protected from weathering by rainfall or breakdown by irradiation and last longer than in other situations. Epiphytic growth and symptom development is very slow with $M$. citri, especially in cooler, drier months. Thus, if a fungicide can protect leaves during the summer, greasy spot may not develop for many months after the 
product is no longer effective. However, even mature leaves are susceptible to infection (7) and it is surprising that effects endure so long.
Apparently a single fungicide application on a mature leaf will prevent infection of the leaf for 15 to 18 months, the useful life of a citrus leaf. Thus, once a growth flush has been sprayed, a second application is not necessary to protect those leaves. Additional sprays may be needed to protect new summer growth or to protect
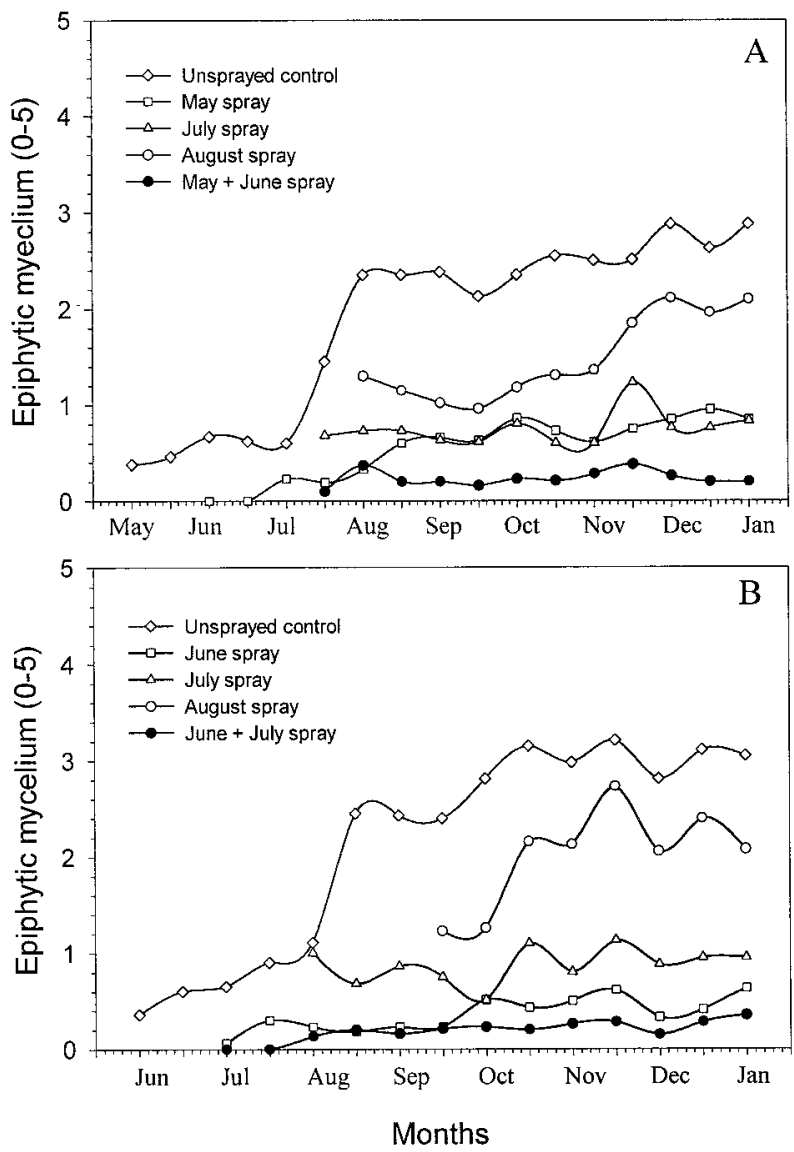

Fig. 5. Epiphytic growth of Mycosphaerella citri on the leaves of spring and summer shoots of grapefruit following treatment of leaves with fenbuconazole. A, spring 2000-01 and B, spring 2001-02.
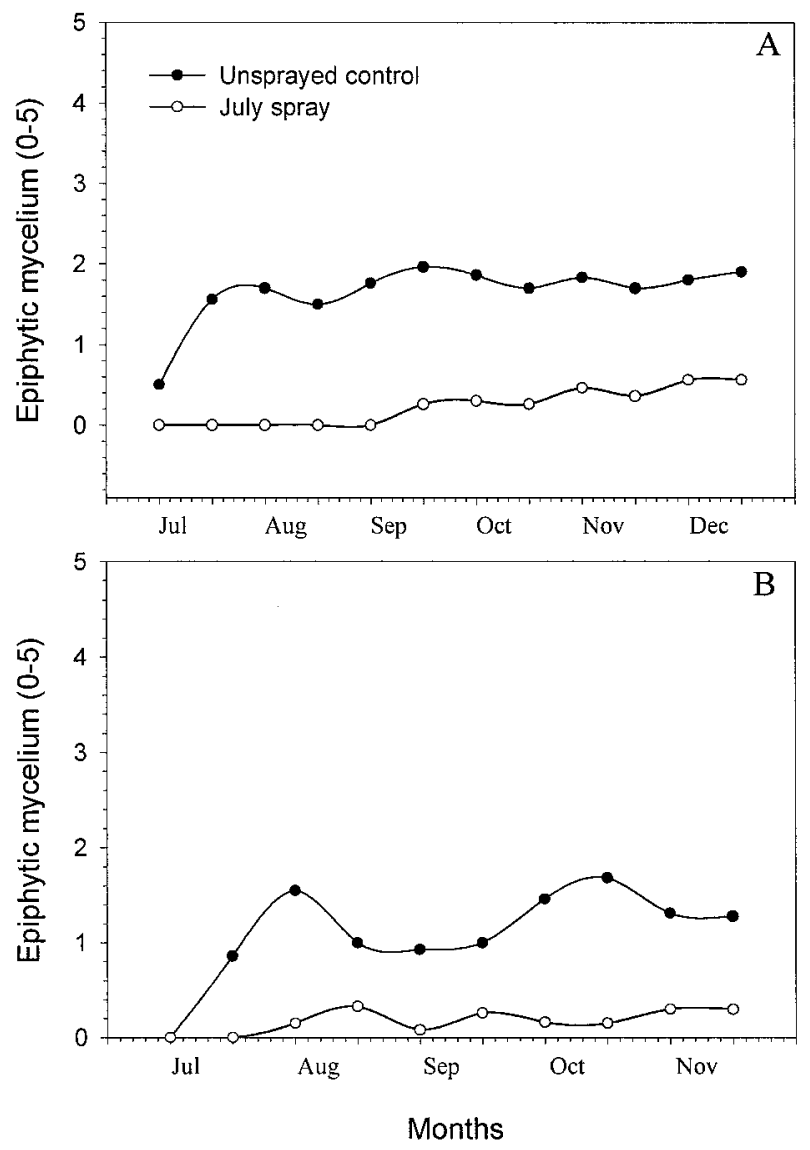

Fig. 6. Epiphytic growth of Mycosphaerella citri on the leaves of summer shoots following treatment of leaves with fenbuconazole in July. A, summer 2000 and $\mathbf{B}$, summer 2001.

Table 1. Greasy spot incidence and severity and defoliation on the spring growth of grapefruit that emerged in March 2000 and was treated with fenbuconazole at different times ${ }^{\mathrm{y}}$

\begin{tabular}{|c|c|c|c|c|c|c|c|c|c|c|c|c|}
\hline \multirow[b]{2}{*}{ Spray time } & \multicolumn{4}{|c|}{ Greasy spot incidence $(\%)$} & \multicolumn{4}{|c|}{ Greasy spot severity $(0-5 \text { scale })^{z}$} & \multicolumn{4}{|c|}{ Defoliation (\%) } \\
\hline & $\begin{array}{c}\text { Dec } \\
2000\end{array}$ & $\begin{array}{l}\text { Mar } \\
2001\end{array}$ & $\begin{array}{c}\text { Jun } \\
2001\end{array}$ & $\begin{array}{c}\text { Sep } \\
2001\end{array}$ & $\begin{array}{c}\text { Dec } \\
2000\end{array}$ & $\begin{array}{l}\text { Mar } \\
2001\end{array}$ & $\begin{array}{c}\text { Jun } \\
2001\end{array}$ & $\begin{array}{c}\text { Sep } \\
2001\end{array}$ & $\begin{array}{c}\text { Dec } \\
2000\end{array}$ & $\begin{array}{l}\text { Mar } \\
2001\end{array}$ & $\begin{array}{c}\text { Jun } \\
2001\end{array}$ & $\begin{array}{l}\text { Sep } \\
2001\end{array}$ \\
\hline May & $7.4 \mathrm{c}$ & $7.4 \mathrm{~d}$ & $18.1 \mathrm{c}$ & $24.6 \mathrm{~d}$ & $0.1 \mathrm{~d}$ & $0.1 \mathrm{~d}$ & $0.3 \mathrm{c}$ & $0.6 \mathrm{~d}$ & 0.0 & $0.3 \mathrm{~b}$ & $1.5 \mathrm{c}$ & $7.8 \mathrm{c}$ \\
\hline May + June & $0.0 \mathrm{~d}$ & $0.0 \mathrm{~d}$ & $0.0 \mathrm{~d}$ & $14.7 \mathrm{~d}$ & $0.0 \mathrm{e}$ & $0.0 \mathrm{~d}$ & $0.0 \mathrm{~d}$ & $0.3 \mathrm{~d}$ & 0.0 & $0.0 \mathrm{~b}$ & $0.0 \mathrm{c}$ & $0.0 \mathrm{~d}$ \\
\hline July & $10.0 \mathrm{c}$ & $21.6 \mathrm{c}$ & $40.6 \mathrm{~b}$ & $43.6 \mathrm{c}$ & $0.2 \mathrm{c}$ & $0.4 \mathrm{c}$ & $1.2 \mathrm{~b}$ & $1.1 \mathrm{c}$ & 0.0 & $0.3 \mathrm{~b}$ & $13.9 \mathrm{bc}$ & $10.5 \mathrm{bc}$ \\
\hline August & $16.9 \mathrm{~b}$ & $43.4 \mathrm{~b}$ & $53.8 \mathrm{~b}$ & $48.5 \mathrm{~b}$ & $0.4 \mathrm{~b}$ & $1.3 \mathrm{~b}$ & $1.8 \mathrm{~b}$ & $2.6 \mathrm{~b}$ & 0.0 & $1.4 \mathrm{~b}$ & $15.7 \mathrm{ab}$ & $20.5 \mathrm{~b}$ \\
\hline Control & $30.4 \mathrm{a}$ & $78.1 \mathrm{a}$ & $93.4 \mathrm{a}$ & $98.5 \mathrm{a}$ & $0.7 \mathrm{a}$ & $2.7 \mathrm{a}$ & $4.0 \mathrm{a}$ & $4.4 \mathrm{a}$ & 0.0 & $12.5 \mathrm{a}$ & $54.1 \mathrm{a}$ & $56.6 \mathrm{a}$ \\
\hline
\end{tabular}

y Values are the means of 10 shoots each on six replicate trees. Mean separation by Waller-Duncan $k$-ratio $t$ test, $P \leq 0.05$.

${ }^{\mathrm{z}}$ Disease severity was rated on a 0 -to- 5 scale, where $0=$ healthy leaves and $5=>20 \%$ area covered with greasy spot.

Table 2. Greasy spot incidence and severity and defoliation on the spring growth of grapefruit that emerged in March 2001 and was treated with fenbuconazole at different times ${ }^{y}$

\begin{tabular}{|c|c|c|c|c|c|c|c|c|c|c|c|c|}
\hline \multirow[b]{2}{*}{ Spray time } & \multicolumn{4}{|c|}{ Greasy spot incidence $(\%)$} & \multicolumn{4}{|c|}{ Greasy spot severity $(0-5 \text { scale })^{z}$} & \multicolumn{4}{|c|}{ Defoliation (\%) } \\
\hline & $\begin{array}{c}\text { Oct } \\
2001\end{array}$ & $\begin{array}{c}\text { Dec } \\
2001\end{array}$ & $\begin{array}{l}\text { Mar } \\
2002\end{array}$ & $\begin{array}{l}\text { May } \\
2002\end{array}$ & $\begin{array}{c}\text { Oct } \\
2001\end{array}$ & $\begin{array}{c}\text { Dec } \\
2001\end{array}$ & $\begin{array}{l}\text { Mar } \\
2002\end{array}$ & $\begin{array}{l}\text { May } \\
2002\end{array}$ & $\begin{array}{c}\text { Oct } \\
2001\end{array}$ & $\begin{array}{c}\text { Dec } \\
2001\end{array}$ & $\begin{array}{l}\text { Mar } \\
2002\end{array}$ & $\begin{array}{l}\text { May } \\
2002\end{array}$ \\
\hline June & $0.0 \mathrm{~d}$ & $1.0 \mathrm{~d}$ & $11.1 \mathrm{c}$ & $9.0 \mathrm{c}$ & $0.0 \mathrm{~b}$ & $0.0 \mathrm{c}$ & $0.1 \mathrm{~d}$ & $0.2 \mathrm{~d}$ & 0.0 & 0.0 & $4.7 \mathrm{c}$ & $0.0 \mathrm{c}$ \\
\hline July & $5.8 \mathrm{c}$ & $15.1 \mathrm{~d}$ & $35.7 \mathrm{~b}$ & $53.5 \mathrm{~b}$ & $0.0 \mathrm{~b}$ & $0.0 \mathrm{c}$ & $0.0 \mathrm{~d}$ & $1.9 \mathrm{c}$ & 0.0 & 0.0 & $5.6 \mathrm{c}$ & $30.9 \mathrm{~b}$ \\
\hline June + July & $0.0 \mathrm{~d}$ & $0.0 \mathrm{~d}$ & $0.0 \mathrm{~d}$ & $2.2 \mathrm{c}$ & $0.0 \mathrm{~b}$ & $0.0 \mathrm{c}$ & $0.0 \mathrm{~d}$ & 0.1 & 0.0 & 0.0 & $0.0 \mathrm{~d}$ & $0.0 \mathrm{c}$ \\
\hline August & $19.0 \mathrm{~b}$ & $51.5 \mathrm{~b}$ & $80.0 \mathrm{a}$ & $85.8 \mathrm{a}$ & $0.2 \mathrm{~b}$ & $1.2 \mathrm{a}$ & $2.6 \mathrm{~b}$ & $3.0 \mathrm{~b}$ & 0.0 & 0.0 & $16.1 \mathrm{~b}$ & $40.1 \mathrm{~b}$ \\
\hline Control & $32.5 \mathrm{a}$ & $69.6 \mathrm{a}$ & $84.4 \mathrm{a}$ & $96.9 \mathrm{a}$ & $0.4 \mathrm{a}$ & $1.5 \mathrm{a}$ & $3.4 \mathrm{a}$ & $4.2 \mathrm{a}$ & 0.0 & 0.0 & $43.2 \mathrm{a}$ & $70.1 \mathrm{a}$ \\
\hline
\end{tabular}

$\mathrm{y}$ Values are the means of 10 shoots each on six replicate trees. Mean separation by Waller-Duncan $k$-ratio $t$ test, $P \leq 0.05$.

${ }^{\mathrm{z}}$ Disease severity was rated on a 0 -to- 5 scale, where $0=$ healthy leaves and $5=>20 \%$ area covered with greasy spot. 
Table 3. Greasy spot incidence and severity and defoliation on summer growth of grapefruit that emerged in June 2000 and was treated with fenbuconazole in July

\begin{tabular}{|c|c|c|c|c|c|c|c|c|}
\hline \multirow[b]{2}{*}{ Treatment } & \multicolumn{4}{|c|}{ Greasy spot incidence (\%) } & \multicolumn{4}{|c|}{ Greasy spot severity $(0-5 \text { scale })^{\mathrm{z}}$} \\
\hline & December 2000 & February 2001 & April 2001 & June 2001 & December 2000 & February 2001 & April 2001 & June 2001 \\
\hline Sprayed & $2.8 \mathrm{~b}$ & $3.1 \mathrm{~b}$ & $6.2 \mathrm{~b}$ & $10.9 \mathrm{~b}$ & $0.04 \mathrm{~b}$ & $0.08 \mathrm{~b}$ & $0.14 \mathrm{~b}$ & $0.23 \mathrm{~b}$ \\
\hline Control & $17.1 \mathrm{a}$ & $27.7 \mathrm{a}$ & $32.6 \mathrm{a}$ & $51.3 \mathrm{a}$ & $0.41 \mathrm{a}$ & $0.54 \mathrm{a}$ & $1.12 \mathrm{a}$ & $1.70 \mathrm{a}$ \\
\hline
\end{tabular}

y Values are the means of 10 shoots each on three replicate trees. Mean separation by Waller-Duncan $k$-ratio $t$ test, $P \leq 0.05$.

$\mathrm{z}$ Disease severity was rated on a 0 -to- 5 scale, where $0=$ healthy leaves and $5=>20 \%$ area covered with greasy spot.

Table 4. Greasy spot incidence and severity and defoliation on summer growth of grapefruit that emerged in June 2001 and was treated with fenbuconzaole in July

\begin{tabular}{|c|c|c|c|c|c|c|c|c|c|c|c|c|}
\hline \multirow[b]{2}{*}{ Treatment } & \multicolumn{4}{|c|}{ Greasy spot incidence (\%) } & \multicolumn{4}{|c|}{ Greasy spot severity (0-5 scale $)^{\mathrm{z}}$} & \multicolumn{4}{|c|}{ Defoliation (\%) } \\
\hline & $\begin{array}{c}\text { Oct } \\
2001\end{array}$ & $\begin{array}{c}\text { Dec } \\
2001\end{array}$ & $\begin{array}{c}\text { Feb } \\
2002\end{array}$ & $\begin{array}{c}\text { Apr } \\
2002\end{array}$ & $\begin{array}{c}\text { Oct } \\
2001\end{array}$ & $\begin{array}{c}\text { Dec } \\
2001\end{array}$ & $\begin{array}{c}\text { Feb } \\
2002\end{array}$ & $\begin{array}{c}\text { Apr } \\
2002\end{array}$ & $\begin{array}{c}\text { Oct } \\
2001\end{array}$ & $\begin{array}{c}\text { Dec } \\
2001\end{array}$ & $\begin{array}{c}\text { Feb } \\
2002\end{array}$ & $\begin{array}{c}\text { Apr } \\
2002\end{array}$ \\
\hline Sprayed & $0.0 \mathrm{a}$ & $0.0 \mathrm{~b}$ & $0.0 \mathrm{~b}$ & $3.6 \mathrm{~b}$ & $0.0 \mathrm{a}$ & $0.00 \mathrm{~b}$ & $0.0 \mathrm{a}$ & $0.13 \mathrm{~b}$ & $0.0 \mathrm{a}$ & $0.0 \mathrm{a}$ & $0.0 \mathrm{~b}$ & $0.0 \mathrm{~b}$ \\
\hline Control & $0.0 \mathrm{a}$ & $42.1 \mathrm{a}$ & $46.6 \mathrm{a}$ & $70.5 \mathrm{a}$ & $0.0 \mathrm{a}$ & $0.72 \mathrm{a}$ & $1.3 \mathrm{a}$ & $2.47 \mathrm{a}$ & $0.0 \mathrm{a}$ & $0.0 \mathrm{a}$ & $35.3 \mathrm{a}$ & $15.4 \mathrm{a}$ \\
\hline
\end{tabular}

$\mathrm{y}$ Values are the means of 10 shoots each on six replicate trees. Mean separation by Waller-Duncan $k$-ratio $t$ test, $P \leq 0.05$.

${ }^{\mathrm{z}}$ Disease severity was rated on a 0 -to- 5 scale, where $0=$ healthy leaves and $5=>20 \%$ area covered with greasy spot.

fruit from greasy spot rind blotch. Fenbuconazole was used in this study, and copper fungicides would appear to have similar long-term effects (8). The effectiveness of petroleum oil and other recommended fungicides (7) is being investigated.

\section{ACKNOWLEDGMENTS}

We thank Zhang Li for technical assistance.

\section{LITERATURE CITED}

1. Hidalgo, H., Sutton, T. B., and Arauz, F. 1977. Epidemiology and control of citrus greasy spot on Valencia orange in the humid tropics of Costa Rica. Plant Dis. 81:1015-1022.

2. Mondal, S. N., and Timmer, L. W. 2002. Environmental factors affecting pseudothecial development and ascospore production of Mycosphaerella citri, the cause of citrus greasy spot. Phytopathology 92:1267-1275.

3. Russo, L. W., and Bistline, F. W. 1992. Results from thirteen-year study to study effec- tive spray timing with greasy spot (Mycosphaerella citri) spore population on east coast and ridge area groves. Proc Fla. State Hortic Soc. 105:19-20.

4. Skaria, M., and Zhang, T. 1996. A leaf disk clearing and staining technique to quantify ascospores of Mycosphaerella citri in young citrus leaves. Subtrop. Plant Sci. 48:16-18.

5. Timmer, L. W., and Gottwald, T. R. 2000. Greasy spot and similar diseases. Pages 25-28 in: Compendium of Citrus Diseases. L. W. Timmer, S. M. Garnsey, and J. H. Graham, eds. American Phytopathological Society Press, St. Paul, MN.

6. Timmer, L. W., Gottwald, T. R., McGovern, R. J., and Zitko, S. E. 1995. Time of ascospore release and infection by Mycosphaerella citri in central and southwest Florida. Proc. Fla. State Hortic. Soc. 108:374-377.

7. Timmer, L. W., Roberts, P. D., and Chung, K.R. 2002. Greasy spot. Pages 73-75 in: 2002 Florida Citrus Pest Management Guide. L. W. Timmer, ed. Publ. No. SP-43. Univ. Fla. IFAS, Gainesville.
8. Timmer, L. W., Roberts, P. D., Darhower, H M., Bushong, P. M., Stover, E. W., Peever, T. L., and Íbañez, A. M. 2000. Epidemiology and control of citrus greasy spot in different citrus-growing areas in Florida. Plant Dis. 84:1294-1298.

9. Whiteside, J. O. 1970. Etiology and epidemiology of citrus greasy spot. Phytopathology 60:1409-1414.

10. Whiteside, J. O. 1972. Effectiveness of spray materials against citrus greasy spot in relation to time of application and infection periods Proc. Fla. State Hortic. Soc. 84:56-63.

11. Whiteside, J. O. 1974. Environmental factors affecting infection of citrus leaves by $M y$ cosphaerella citri. Phytopathology 64:115120.

12. Whiteside, J. O. 1977. Behavior and contro of greasy spot in Florida citrus groves. Proc. Int. Soc. Citricult. 3:981-986.

13. Whiteside, J. O. 1982. Timing of single-spray treatments for optimal control of greasy spot on grapefruit leaves and fruits. Plant Dis. 66:687-690. 